undoubtedly much greater and more prolonged than was actually required for the purposes of the experiment, the temperature of the kiln being not less than 1,200 degrees Cent. The bubbles are too large to show Brownian movement.

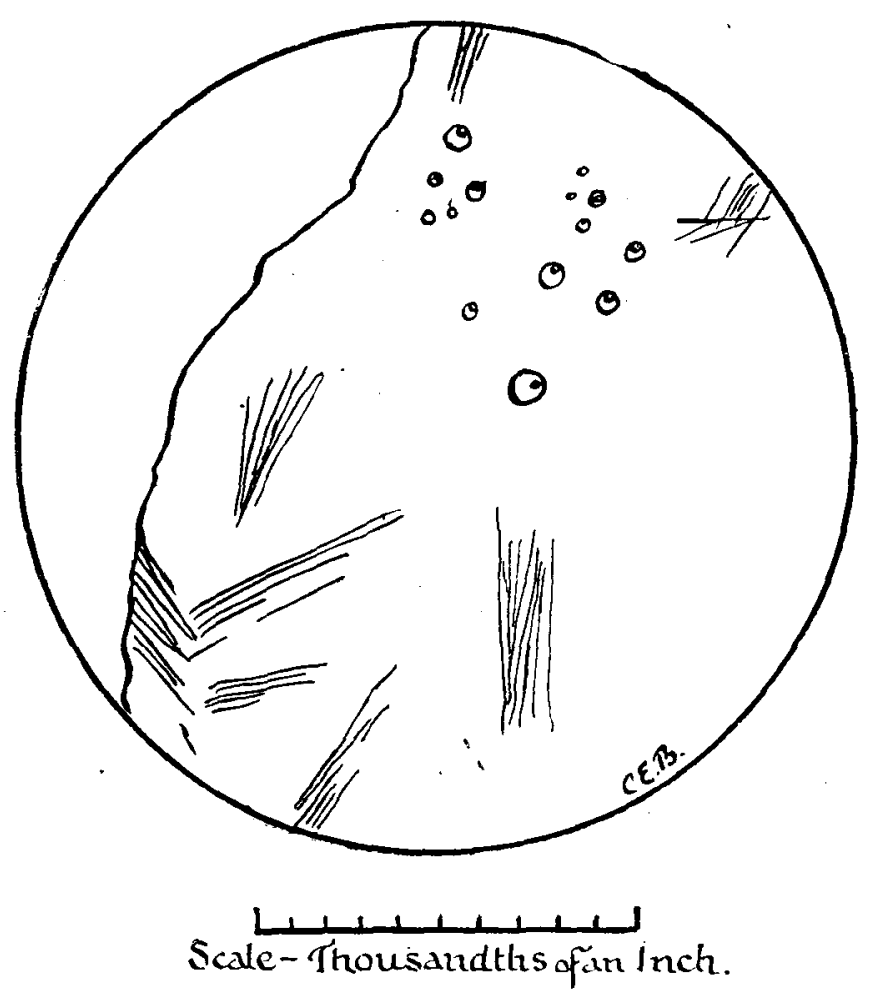

Frg. 3.-Liquid inclusions obtained in glass by heating a sealed tube containing water beyond the critical temperature.

P.S.-Since writing the above I have repeated the experiment with similar success, and on this occasion some of the numerous inclusions show Brownian movement of the enclosed bubble. -C. E. B.

\title{
The Igneous Complex of Y Foel Fras, Caernarvonshire.
}

By Norman L. Silvester, B.Sc., F.R.Met.Soc.

THE area under consideration is a portion of the mountain massif bounded on the east by the Conway River, on the north by the narrow coastal plain between Conway and Bangor, and on the west and south by the popular tourist route through Nant.-Francon pass by Llyn Ogwen and down the Afon Llugwy to Bettws y coed. 
The investigation includes the horseshoe-shaped ring of mountains, of which the highest is Y Foel Frâs (3,091 feet), surrounding the upper course of the Aber River (Cwm yr Afon Goch). To the north-west this igneous complex is bounded by the precipitatious crags over which the above stream descends by leaps and bounds, forming the well-known Aber Falls. Upon Sheet 78, south-east of the old Geological Survey map the area is coloured as "Massive intrusive felspathic rocks", surrounding two oval patches indicated as "Greenstones", whilst a further elongated patch of the latter forms the south-west boundary. The north-east boundary is limited by the Aber-Llanbedr fault. Besides the hog-backed summit of Y Foel Frâs, the area includes the similarly outlined summits of Y Drosgl West ${ }^{1}$ (2,483 feet), Yr Arryg (2,875 feet), Llwydmor Bâch (2,256 feet), and the more rugged summits of Bera Mawr (2,587 feet), Bera Bâch and Llwydmor (2,749 feet).

A study of this area commenced early in the summer of last year shows that the map will require considerable modification. The north-west boundary consists of a lenticular outcrop of augitic granophyre, nearly 3 miles in length, from north-east to south-west, and reaching a maximum width of about 1,200 yards at $Y$ Drosgl West. The microstructure of the rock has been described by Dr. Harker ${ }^{2}$ and an analysis published. The mass is undoubtedly intrusive as Ramsay remarks, ${ }^{3}$ as for distances varying between about 30 and 100 feet from the contact the slates are baked to porcellanite. It is evident, however, that Ramsay mistook the baked slate which weathers yellow for the chilled edge of the intrusion. He mentions that the intrusion edge " rises like a wall, is fine grained and weathers yellow". A careful examination of the junction at the falls of the Afon Bâch shows that it is not at all regular, but that the granophyre sends veins into the baked sedimentaries. Also it is noticed that it is the indurated baked slate that forms the walls of the precipice in most places, and it is seen that this metamorphosed rock weathers better than the intrusion. This is well shown on the summit of Gyrn Wigau, where the only exposure is a well-defined ridge running from north to south, composed of this dark-grey porcellanite, weathering pale yellow, while the outcrop of the granophyre to the east of the ridge can be deduced only from scattered blocks.

The thermo-metamorphism of the contact rock is less pronounced than would be anticipated from the dimensions of the intrusion. A micro-slice cut from a specimen from the exposure at the lesser Aber Falls " shows no distinct recrystallization except for minute grains of magnetite which increase in number towards the junction.

1 It is necessary to add the suffix "West" to distinguish this mountain from the other of the same name 3 miles north-east, i.e. between Foel Fras and Tal-y-fan.

2 A. Harker, Bala Volcanic Series of Rocks, pp. 41-8.

3 Ramsey, Geological Survey Memoir $N$. Wales, pp. 138-9.

4 Lent by Dr. E. Greenly. 
By reflected light there seems to be a faint indication of the development of two minerals producing a vague spotted appearance.

At the base of the Aber Falls the slate shows distinct spotting in the hand specimens. This rock when sliced will probably reveal a greater development of contact minerals.

The granophyre, when followed up either the Afon Bâch or the Cwm yr Afon Gôch, becomes first much coarser in texture, then at a distance of 200 feet from the falls junction develops patches of darker hue, in which the dark minerals are segregated. Further

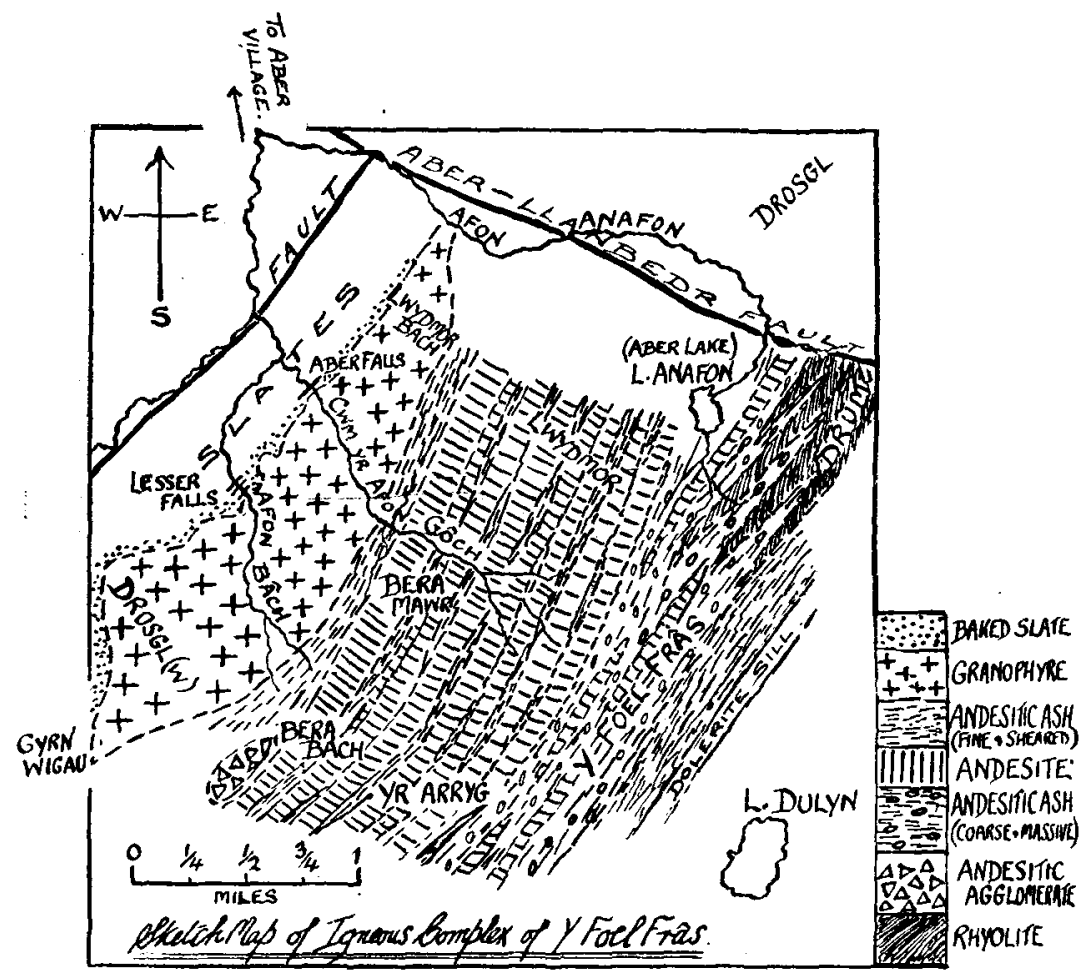

FrG. 1.-The Igneous Complex of $\mathrm{Y}$ Foel Fras.

upstream the rock becomes more fine-grained and darker and more homogeneous in the hand specimen, but still with occasional patches of coarser grain. Near the south-eastern margin of the intrusion the rock becomes sheared. This is of interest, as it appears to be evidence in favour of the theory put forward by Dr. A. Harker that the direction of the thrust which produced the great earth-movements in Bala times was from the south-east. There are no signs of shearing on the north-west margin. This phenomenon is best seen on the summit of Llwydmor Bâch. 
No good exposure of the junction between the granophyre and the sheared andesitic ashes which succeed in outcrop in a south-east direction has as yet been found. This is owing to the comparative ease with which the latter beds have weathered-the weathering being assisted by the vertical cleavage. In neither of the abovementioned streams is there any exposure-the solid geology of this area being obscured by drift. This band of ashes outcrops parallel to the general trend of the granophyre over a width of about 600 feet. It can be followed from the saddle between Llwydmor and Llwydmor Bâch across the Cwm yr Afon Gôch and up the northern slopes of Bera Mawr. The rock is hopelessly weathered, with abundant felspars showing occasionally a kernel of unweathered plagioclase.

Continuing the traverse up the Cwm yr Afon Gôch, the sheared ashes are succeeded by massive lava flows composed of andesite intercalated with sheared ashes of similar composition. Over these the stream rushes in a series of cascades, whilst in two places the stream has cut back its bed so that it now runs through a miniature cañon 30 feet deep and only 5 to 10 feet wide at the top. The andesite is usually of a dark-grey colour with conspicuous and numerous plagioclase phenocrysts. It weathers in the first stage to a greenish rock in which the felspars appear white. At a further stage-well seen in the exposed summits of Bera Mawr and Bera Bâch--the weathering agency has selected the felspar phenocrysts for destruction, so that the surface presents a rough vesicular appearance and is quite palegrey with a lilac tinge. Owing to their proneness to weathering, the vesicular selvages of the individual flows are rarely exposed. The edge of the first flow is exposed in the crags on the left bank of the Afon Gôch just above the sheared ashes. Evidence from the orientation of the felspar phenocrysts and from measurements of the vesicular selvages of the flows, points to the fact that the strike of these lavas is S.S.W.-N.N.E., and the dip about $90^{\circ}$. These flows, with few intercalations of ashes, outcrop for about 1 mile in the direction of dip before they are succeeded by another andesitic series in which ashes predominate over flows. Many of these ashes are as massive and resistant to weathering as the massive flows which form the rugged summits of Bera Mawr, Bera Bâch, and Llwydmor. They are coarser than the sheared ashes, described above, the fragments of scoria occasionally measure 3 inches in diameter. They form the upper north-west slopes and summit of Foel Frâs. Near the summit the effects of pressure again become evident, as these beds when traced down the opposite south-east flank become gradually more sheared.

The massive andesites can be traced in the direction of their strike, a distance of over 2 miles from the western shore of Lake Anafon over Llwydmor and Bera Mawr to Bera Bâch. It has not been found possible up to the present to distinguish the individual 
flows in the field by means of petrographic differences. The summit of Lwydmor as viewed from the valley of the Anafon below the lake consists of a succession of five flows whose basset edges stand out boldly against the skyline like the castellations on a castle wall, whilst on Bera Mawr they number six.

The proximity of the vent from which this andesitic series was extruded seems clearly evident from the occurrence immediately to the west of Bera Bâch of a small outcrop of coarse agglomerate or breccia consisting of large fragments of fine-grained vesicular andesite measuring as much as $2 \mathrm{ft} .6 \mathrm{in}$. in length. The interstices are filled with smaller fragments of ash, and the cementing material is a soft, dark slate in which no fossils could be found. Exposed as they are at a height of over 2,000 feet to the full force of the prevalent winds, these agglomerates are deeply weathered to a uniform pale grey, looking remarkably like weathered rhyolites in the distance. As the cementing material has weathered faster than the lava blocks, the latter stand out from the surface so as to resemble the loose débris of a recent eruption. The dip of the longer axes of most of the blocks is south-east at $70^{\circ}$ to $80^{\circ}$.

According to Dr. Harker ${ }^{1}$ the whole of the area consists of the plug of a vast volcano built on the site of and partly out of the fragments of an older vent. This hypothesis readily removes the difficulty of explaining the sudden disappearance of the series when traced in the direction of the strike to the north-east. It will also explain the vertical position of the lava flows if it is assumed that the plug successfully resisted the later earth-movements without being thrown out of the vertical. It is, however, not easy to account for the persistence of the strike of the lava flows. If they are merely the feeders which supplied the material for the ashes and for flows since removed by denudation, it is to be expected that their outcrop in cross section would be approximately circular unless the eruption were of the fissure type. If, on the other hand, this series represents the remains of a normal succession of flows and intercalated ashes originally laid down horizontally but since thrown on edge by crust movements, we have a succession nearly 2 miles thick comparable in magnitude to the Borrowdale series in the Lake District. At the eastern extremity of the area, as in the succession exposed in Pant y Mynach to the south of L. Anafon, rhyolitic flows and ashes become intercalated with the andesitic series. This rhyolitic series thickens north-eastward, but dies out in the opposite direction between Foel Frâs and Llwydmor. It therefore appears that the vicinity of Llyn Anafon is an area intermediate between two vents, one near Bera Bâch pouring out andesitic material simultaneously with another to the north-east ejecting more acid material. Ashes formed of fragments of both kinds are found on the west shore of Llyn Anafon.

1 Harker, Bala Volcanic Series of Rocks, p. 127. 
Evidence for the Aber-Llanbedr fault has been found near the source of a small tributary which enters the right bank of the Afon Anafon 500 yards below the lake, where rhyolites are found faulted against contorted slates. Fault breccias provide further evidence 500 yards lower down the Anafon, and also near the northeastern extremity of the granophyre laccolith in the groove cut by a small stream which enters the left bank of the Anafon after draining the north slopes of Llwydmor Bach.

The area to the north-east and north-west of Llyn Anafon is much disturbed by faulting and needs further investigation. The work is being continued, and it is hoped that a map of the area on the 6 inch scale will be published at a later date together with a more detailed account. 